\title{
КОЗАЦЬКІ ЛІТОПИСИ ЯК ПРОТОТЕКСТИ
}

\author{
ЮЛІЯ ШПАК \\ Харківський національний педагогічний університет імені Г. С. Сковороди, \\ Харків - Україна
}

\section{LATOPISY KOZACKIE JAKO PROTOTEKSTY}

\author{
JULIA SZPAK \\ Charkowski Narodowy Uniwersytet Pedagogiczny im. H. Skoworody, \\ Charków — Ukraina
}

STRESZCZENIE. Artykuł poświęcony jest ustaleniu typów tekstów, z którymi latopisy kozackie wchodzą w relacje międzytekstowe jako prototeksty. $\mathrm{Na}$ podstawie materiału językowego wyodrębniono zasadnicze grupy intertekstów i rodzaje elementów intertekstowych, za pomocą których realizowane są związki intertekstowe między badanymi utworami.

\section{COSSACKS CHRONICLES AS PRECEDENT TEXTS}

\author{
IULIIA SHPAK \\ H. S. Skovoroda Kharkiv National Pedagogical University, \\ Kharkiv — Ukraine
}

\begin{abstract}
The article is dedicated to defining types of the texts which interact with Cossacks chronicles as precedent texts. Due to the examination of the proper language material it was possible to single out the essential groups of intertexts and types of intertextual elements (intertextemes) with the help of which the intertextual connections between the examined texts are implemented.
\end{abstract}

$\mathrm{Y}$

сучасному мовознавстві комплексні дослідження тексту, зокрема аналіз проблем прецедентності й інтертекстуальності текстів різних дискурсів, не втрачають своєї актуальності.

Вивчення інтертекстуальності як категорії тексту почалося в літературознавстві (М. Бахтін, Ю. Тинянов, J. Stephens та ін.) і філософії мови (М. Ямпольський, J. Derrida, M. Foucault та ін.). Представники школи постструктуралізму (R. Barthes, J. Kristeva) і семіотичного напряму (J. Culler, M. Riffaterre) заклали основи лінгвістичних досліджень проблематики інтертекстуальності й прецедентності, що стали підгрунтям розвитку теорії інтертекстуальності (I. Арнольд, Г. Денисова, 3. Тураєва, Н. Фатеєва).

У процесі розвитку цієї теорії виокремилися такі основні поняття, як текстприймач (інтертекст) - текст, у якому присутнє інтертекстуальне покликання; прототекст (прецедентний текст) — текст, на який робиться посилання; $i$ тертекстема — конкретна вербалізація інтертекстуального посилання на прототекст у тексті-приймачі та аспекти прецедентності - окремі структурносемантичні елементи прототексту, що актуалізуються в процесі інтертекстуальних взаємодій. Дослідження інтертекстуальності тексту неможливе без вивчення прецедентного тексту як передумови інтертекстуальних відносин і складової фонових знань окремої лінгвокультурної спільноти, що було розпочато в наукових працях В. Карасика, Ю. Караулова, В. Кухаренко, Г. Слишкіна. 
Аплікація прагматичного підходу до опису різних мовних явищ, серед яких $\epsilon$ i текст, спричинює появу лінгвостилістичних досліджень, що мають переважно прикладний характер і аналізують засоби реалізації інтертекстуальності в конкретних текстах (Л. Грек, О. Рябініна, Н. Сунько, Ю. Шпак та ін.) для того, щоб установити, який прагматичний потенціал містить той чи той текст.

Завдяки інтертекстуальності в тексті відбувається трансформація інформації від попередніх шарів культури до наступних або між одночасно існуючими різними видами мистецтва та формами культуротворчої діяльності. Інтертекстуальність є такою категорією, що характерна не лише для художніх текстів, але й для публіцистичних, наукових тощо, сучасних і попередніх художньоестетичних форматів. Літописи Самовидця, Г. Граб'янки та С. Величка, що в літературознавчому науковому обігу називають козацькими літописами, є виразними пам'ятками українського літературного бароко. У попередніх своїх працях авторка цієї статті вже довела, що козацькі літописи є художньоісторіографічними текстами, в яких спостерігаються різні види інтертекстуальності. Їхні інтертекстуальні зв'язки реалізуються завдяки таким типам інтертекстем, як цитати, алюзії, ремінісценції, репродукції, перекази, переклади, інтертекстеми як тропи та стилістичні фігури, інтермедіальні тропи та стилістичні фігури, запозичення прийому тощо ${ }^{1}$. Але, як відомо, певні тексти, а саме згадані літописи, стають одночасно інтертекстами й прототекстами.

У цій статті ставимо мету схарактеризувати види текстів, із якими козацькі літописи вступають у міжтекстову взаємодію як прототексти.

Спираючись на широке трактування тексту в межах семіотичного напряму (I. Арнольд, Ю. Лотман, I. Смирнов, О. Селіванова, J. Derrida), за онтологічним статусом козацькі літописи належать до суцільно вербальних текстів (літопис Самовидця) і текстів із невербальними елементами (літопис Г. Граб'янки і С. Величка).

Складність відстеження прокурсивних інтертекстуальних зв’язків козацьких літописів пов'язана 3 тим, що існують списки або частини оригінальних творів українською мовою к. XVII - поч. XVIII ст. та їхні переклади сучасною українською мовою. Отже, як перші, так і другі слугують джерелами інформації для створення нових змістів і сьогодні. У цій розвідці вважаємо за прототексти усі наявні публікації козацьких літописів.

Зауважимо, що всі три літописи привернули увагу насамперед дослідників історії в сер. ХІХ ст. завдяки праці членів Київської Тимчасової комісії з розгляду давніх актів. Упродовж 1848-1864 рр. комісія надрукувала Літопис С. Величка, що складається $з$ двох частин та чотирьох томів. Літопис Граб'янки вперше був опублікований 1793 р. в журналі Ф. Туманського „Российский магазин”, але там не було вказане ім'я автора твору. Члени комісії, готуючи 1853 р. видання пам'ятки, не знали про публікацію Ф. Туманського і вважали, що вводять літопис Граб'янки в науковий обіг уперше. Оригінал рукопису не зберігся, про популярність твору свідчить рекордна кількість списків - на сьогодні, разом із нововідкритими та реконструйованими, дослідники нараховують їх понад 50. Іншим відомим козацьким літописом є Літопис Самовидия. До 1846 р., поки цей літопис не був опублікований з ініціативи П. Куліша О. Бодянським. Твір існував у рукописному варіанті. Знову він був виданий Київською Тимчасовою комісією з розгляду давніх актів 1878 р.

${ }^{1}$ Ю. Ш п а к, Інтертекстуальність у мовному світі козацьких літописів, Автореф. дис. канд. філол. наук, Харків 2012, с. 18. 
Назва Літопис Самовидия не $\epsilon$ авторською². П. Куліш запропонував назвати ії так, визначивши, що це історичне джерело було створене сучасником подій (потім цей іменник став писатися з великої літери як ім'я).

Більш розлогими $є$ заголовки двох інших козацьких літописів: Григорія Граб'янки — Днебывалой брани Богдана Хмелницкого, гетмана Запорожского, съ поляки... въ року 1648, отправоватися начатой и за ль:тъ десять по смерти Хмелниц-

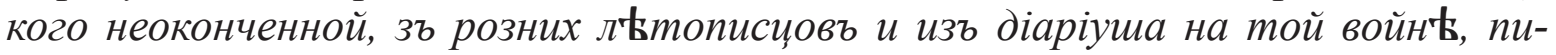
санного въ градњ Гадячу, трудом Григорія Грабянки, собранная и самобитнихъ старожсиловъ свьдительстви утвержденная - та Самійла Величка, літопис

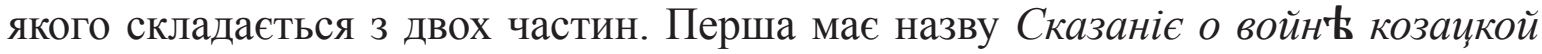

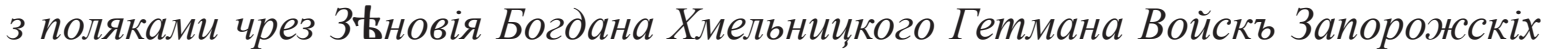

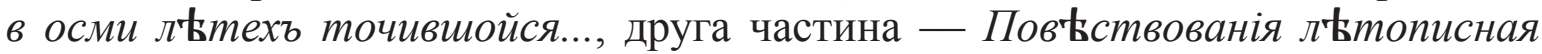
о малоросийськихъ и инихъ от части поведеніяхъ собранная и зде описанная.

Ще за часів існування рукописів і списків зазначених творів ними як джерелами для запозичень користувалися інші автори. Так, відомо, що Г. Граб'янка звертався до літопису Самовидця, створюючи свою хронічку. С. Величко скористався твором Г. Граб'янки. М. Маркевич активно залучав для висвітлення вітчизняного минулого Iсторію Русів та літопис Г. Граб'янки в працю Історія Малоросії ${ }^{3}$.

Отже, першу групу текстів, у яких реалізується інтертекстуальний зв'язок 3 козацькими літописами, складають історіографічні тексти XIX ст. Нагадаємо, що один із списків літопису Самовидця був відомий українському історикові др. пол. XVIII ст. О. Рігельманові, який переклав його російською мовою і дослівно заніс до своєї відомої праці про Україну Літописна оповідь про Малу Росію та ї̈ народ і козаків узагалі4. Компілятивні праці Я. Лизогуба і В. Рубана прямо або опосередковано теж ведуть до літопису Г. Граб'янки.

Німецький історик Йоганн-Бенедікт Шерер (1741-1824) ${ }^{5}$ і його співвітчизник Гаммер-Пургшталь Йозеф (1774-1856) - німецький орієнталіст, автор книги Османська імперія: державний устрій і управління (1816) - помістили до своїх творів переклад Короткого опису Малоросії, що був написаний на підставі літопису Самовидця.

Друга група інтертекстів репрезентована найширше, оскільки до неї належать наукові дослідження з історії, літературознавчі студії, лінгвістичні дослідження різних напрямів, з історії української мови та літератури тощо. Серед відомих істориків, у працях яких знаходимо прямі посилання та цитування козацьких літописів, зустрічаємо Д. Багалія, М. Грушевського, О. Левицького, Г. Карпова, М. Костомарова, І. Крип'якевича, О. Лазаревського, О. Левицького 6 , М. Петровського, Д. Яворницького. М. Максимович багато працював з літописами в царині історії та філології7.

${ }^{2}$ Я. І. Дз и р а, Вступ, [в:] Літопис Самовидия, Київ 1971, с. 1-3.

3 I. Дзира, Козачькі літописи 30-80-x рр. ХVIII століття як історичне джерело та пам'ятки украӥнської історіографії, [в:] Електронний ресурс: http://www.medievist.org. ua/2013/01/3080-xv.html (16.06.2013).

${ }^{4}$ Там само.

${ }_{5}^{5}$ Ж. - Б. Ш е ре р, Літопис Малоросії, або Історія козаків-запорожиів та козаків України, або Малоросії, пер. з фр. В. В. Коптілов, Київ 1994.

${ }^{6}$ О. Л Л в и ц к и й, Опыт исследования о летописи Самовидия, [в:] Летопись Самовидиа по новооткрытым спискам, Київ 1878, с. 1-75.

${ }^{7}$ М. А. Макс и мо в и ч, Собрание починений в 3-х m., Киев 1876, т. 1. 
У той час, коли історики дискутували з приводу достовірності козацьких літописів, мовознавці, серед яких О. Огоновський, М. Петров, Л. Житецький, М. Возняк, О. Білецький, досліджували мовні особливості зазначених творів.

У наш час ці тексти також не перестають привертати увагу дослідників мови з питань семантики, граматики, лексики, інтертекстуальності. Так, граматичні особливості мови літопису Самовидця дослідив I. Петличний ще 1956 p. ${ }^{8}$. У праці С. Бевзенка викладені результати спостереження над синтаксисом українських літописів XVII ст., зокрема літописів Самовидця і С. Величка9. Цікаве дослідження побутової лексики, зафіксованої літописами Самовидця, С. Величка та Г. Граб’янки, здійснила О. Крижко 1998 р. ${ }^{10}$.

Дослідження мовних особливостей Літопису С. Величка на рівнях синтаксису, лексики та фразеології здійснювали П. Плющ, І. Білодід, В. Русанівський, М. Грицай, В. Крекотень. Їхні висновки подані в різних виданнях, присвячених історії української літературної мови або української літератури, зокрема й періоду українського бароко.

Мовний світ літопису С. Величка привертає увагу багатьох науковців. Наукове дослідження фонетичних рис літопису С. Величка та особливостей їх передачі на письмі належить О. Волоху, який у дисертації Фонетические особенности языка летописи С. Величко (1963 р) докладно схарактеризував це питання.

Після перевидання в др. пол. ХІХ ст. літописів Самовидця, Г. Граб'янки i C. Величка вони привернули увагу й літературознавців. Якісно новий рівень осмислення літопису Самійла Величка як твору не лише історичного, публіцистичного, наукового, а й художнього констатуємо в працях I. Франка. Услід за О. Пипіним, В. Спасовичем (История славенских литератур, Петербург 1865), I. Прижовим (Малороссия (Южная Русь) в истории ее литературы с XI по XVIII век, Воронеж 1869), О. Огоновським (История литературь русской, Львів 1887) І. Франко вводить твір С. Величка у працю синтетичного характеру з історії літератури (Історія української літератури, 1909), систематичні курси історії літератури, енциклопедичні видання. (Нарис Южнорусская литератуpa, нап. І. Франком для 81 тому Энииклопедического словаря Ф. А. Брокгауза и И. А. Эфрона) ${ }^{11}$. Це сприяло тому, що про літопис С. Величка дізналися й культурні кола за межами України.

I. Франко вказував, що „власне в козацьких літописах Самовидця, Граб’ янки, Величка i їх наступників і компіляторів, зокрема таких, як Боболинський, Лукомський, Рігельман і т. п., було б інтересно прослідити зріст тої легенди про Хмельниччину, що в значній мірі заслонила перед нами правдиву дійсність. 3 літературного погляду се було явище дуже цінне, здібне будити запал у широких масах народу; аж у XIX віці ми побачили його значення для національного відродження і формування наших політичних ідеалів <... Отся грандіозна конструкція Хмельниччини, конструкція більше літературна, аніж історична, була $<$... > головною заслугою козацьких літописів"12.

${ }^{8}$ I. 3. Пе тл ичн и й, Граматичні особливості мови літопису Самовидия, [в:] „Питання українського мовознавства" Львів 1956, кн.1, т. 1, с. 76-99.

${ }^{9}$ С . П. Б е в зе н ко, Спостереження над синтаксисом українських літописів XVII cm., [в:] „Наукові записки Ужгородського університету” Ужгород 1954, т. 9, с. 165-243.

${ }^{10} \mathrm{O}$. А. К р ижко, Розвиток семантики побутової лексики украӥнських літописів кіния XVII - початку XVIII cm. (назви їжі, напоїв, продуктів харчування), Київ 1998.

${ }^{11}$ І . Я. Фран ко, Літературно-критичні праці (1897-1899), [в:] його ж, Зібрання творів у 50 m., Київ 1981, т. 31 .

${ }^{12}$ I. Я. Франко, Історія украӥнської літератури, Частина периа. Від початків украӥнського письменства до Івана Котляревського, [в:] його ж, Зібрання творів у 50 т., Київ 1983, т. 40 , c. 321-347. 
Отже, I. Франку першому судилось не лише привернути увагу до козацьких літописів як до творів художньо-літературних, а й накреслити перспективи майбутніх досліджень, що будуть розгорнуті в працях Я. Дзири, Д. Чижевського, Д. Наливайка, М. Возняка.

Одним із перших сучасних літературознавців спробу дослідити твір Г. Граб'янки зробив М. Зеров. Йдеться про курсову роботу, яку М. Зеров пізніше в автобіографіï 1928 р. назвав Літопис Граб'янки як історичне джерело $i$ літературна пам'ятка. Виконана вона під керівництвом доцента В. Данилова. У фонді письменника зберігся їі чорновий варіант (без назви) ${ }^{13}$. Ретельним дослідженням цього твору є наукова робота Ю. Луценко, в якій здійснено літературознавчий аналіз літопису ${ }^{14}$.

Такі вчені, як Ф. Колесса, Я. Дзира, М. Грицай, Д. Чижевський, В. Шевчук, О. Мишанич, В. Крекотень, Л. Ушкалов приділили багато уваги аналізу художніх особливостей літопису С. Величка. В. Соболь, Б. Небесьо, В. Крекотень уважають, що треба не нехтувати Величковою манерою подавати матеріал „витиевато или живописно"15, а вникнути в суто Величкові прикмети „вишуканого, надмірного й роздутого поетичного стилю", тоді зрозумієш істинні скарби та найбільш значущі достоїнства цього найзагадковішого в українській історіографії твору.

Третю, найцікавішу з огляду на реалізацію інтертекстуальної взаємодії групу складають твори художньої літератури. Відомо, що Тарас Шевченко досконало знав козацькі літописи, зокрема твір С. Величка, й активно користувався ними під час написання творів на історичні теми. Працюючи в київській Тимчасовій комісії з розгляду давніх актів (1845-1847 рр.), Т. Шевченко двічі приїздив у Москву до О. Бодянського, який був добрим знавцем стародавніх українських пам'яток і мав велике їх зібрання. Пізніше, перебуваючи в засланні, поет спочатку просив передати йому тексти літописів, а потім писав О. Бодянському: „Спасибі тобі ще раз за літописи, я їх вже напам'ять читаю. Оживає моя мила душа, читаючи їх. Спасибі тобі!"16. Відомий літературознавець Я. Дзира стверджував, що такі твори Т. Шевченка, як Чигирине, Чигирине; Великий льох; І мертвим, і живим, І ненародженим землякам моїм... та низка віршів, зокрема Три літа, мають історичною фактологічною основою літопис С. Величка. Т. Шевченко черпав з літопису не тільки уявлення про минуле України, а й брав з нього матеріал для висвітлення постатей гетьманів і багато іншого, аж до окремих образів, порівнянь, метафор.

Велич і красу козацької звитяги Т. Шевченко розкриває в поемах Іван Підкова, Гамалія, Тарасова ніч, Гайдамаки. Картину волелюбства й мужності українського козацтва в боротьбі з турецько-татарськими ордами показано в поемі Гамалія. Образ Кобзаря теж навіяний безсмертним твором С. Величка. У Шевченка, як і у Величка, простежуємо козацьке розуміння релігії й національне трактування Біблї, яку вони використовували для пояснення болісних і трагічних явищ у житті рідного народу ${ }^{17}$.

${ }^{13}$ Ю . Лу ц е н ко , Біля джерел, [в:] „Вітчизна” Київ 1989, вип. № 5, с. 137-139, [в:] Електронний ресурс: http://www.ursr.org/vitchyzna/89/05/html/138.html (12.03.2013).

${ }^{14}$ Ю. М. Луце н ко, Григорій Граб'янка і його літопис, [в:] Літопис гадяиького полковника Григорія Грабянки, Київ 1992, с. 3-9.

${ }^{15}$ В. С. Икон н и ко в, Опыт русской историографии, Киев 1908, т. 2, кн. 2.

${ }^{16}$ Т. Г. Ше в чен ко, Повне зібрання творів у 12 m, Київ 2003, т. 6, с. $79-80$ (текст), с. 370371 (примітки).

${ }_{17}$ Я. Дзи и а, Козацький правопис поета (Чи маємо академічне видання творів Тараса Шевченка?), [в:] Mappa mundi, Львів 1996, с. 616-634, [в:] Електронний pecypc: http://litopys.org. ua/rizne/dzyra.htm (16.05.2013). 
Таке використання джерел було природне для давнього українського письменства. Про це свідчить творчість Т. Шевченка, М. Костомарова, I. НечуяЛевицького, І. Франка й інших художників слова.

У той час, коли Т. Шевченко писав вірші Три літа, а М. Костомаров грунтовне дослідження з історії України Богдан Хмельнищький, історична концепція, важливим чинником формування якої стали козацькі літописи, відбивалася також у романах. Саме з цих автентичних джерел автори історичних романів черпали уявлення про найхарактерніші риси суспільної ментальності, колоритні характери, виробляли систему оцінок і переконань із релігійної, громадськополітичної та побутової сфери життя суспільства XVII ст.

Прототекстом історичного роману Чорна рада. Хроніка 1663 p. П. Куліша є Літопис Самовидия, про що й сам П. Куліш пише в епілозі. „На задум Чорної ради наштовхнули його козацькі літописці - Самовидець і Граб'янка. Вони підказали П. Кулішеві центральну постать старого Шрама. Характерно, що ні польські аматори старовини, ні шляхтич Срлич, один із малоросіян, "противодействовавших" Б. Хмельницькому, не відхилили П. Куліша від його трактування”, писав Микола Зеров ${ }^{18}$. Змальовуючи детально картину „чорної ради”, П. Куліш довіряє Самовидцеві як свідкові, єдиному літописцеві й сучасникові, що зобразив ііі до дрібниць, що доведено порівняльним аналізом усіх трьох козацьких літописів. Зрозуміло, що романіст не може дозволити собі наслідувати літопис дослівно, він творчо трансформує знайдені ідеї та образи. Інтертекстемами, що відсилають нас до козацьких літописів, насичений текст Чорної ради: від зображення становища українського суспільства напередодні національновизвольної війни й до останнього розділу роману (страта Сомка і смерть Шрама). П. Куліш писав текст водночас російською й українською мовами, що дещо відмінні за викладом. М. Зеров відзначає „більшу розволоклість” російського тексту. Кожен його розділ починається епіграфом із народної думи або пісні ${ }^{19}$.

Трилогія Богдан Хмельницький М. Старицького нагадує детальний белетризований виклад історії Визвольної війни 1648-1654 рр., однак чимало місця автор відводить творчому домислу та вигадці, надає перевагу авантюрнопригодницьким епізодам і лірико-романтичним відступам. Узявши за основу трилогії Богдан Хмельницький однойменну монографію М. Костомарова, М. Старицький не в усьому погоджується з істориком. Письменник неодноразово звертається до літопису Величка як автентичного джерела, в якому події подані більш логічно: напад Дачевського на Хмельницького, арешт останнього в Бужині, зустріч із реєстровими козаками на Дніпрі та інші. Крім Б. Хмельницького, як центральної постаті, письменник звертає увагу й на Максима Кривоноса та Івана Богуна, які оспівані більше в народних піснях, легендах та ду$\operatorname{Max}^{20}$.

I. Нечуй-Левицький теж долучився до розвитку історичного роману, написавши твір Гетьман Іван Виговський (1898). У бібліотеці Левицького-старшого (жила уся його родина в містечку Стеблів) були твори знаних істориків: Д. Бантиш-Каменського, М. Маркевича, а також козацькі літописи Величка, Са-

${ }^{18}$ М. 3 е р о в, Куліш: Чорна Рада, [в:] Твори в 2 т., Київ 1990, т. 2, с. 196-203.

${ }^{19}$ М. Зер ов, Від Куліша до Винниченка, нариси з новітнього українського письменства: передмова, [в:] Твори в 2 m., Київ 1990, т. 2, с. 246.

${ }^{20}$ Н. Т. Бо йко, Украӥнська історична проза другої половини XIX cm. (Iсторичні джерела та художній дискурс),Київ 2002, с. 7, [в:] Електронний pecypc: http://referatu.net.ua/ referats/7569/144310 (20.06.2013). 
мовидця та Граб'янки. Не варто забувати й про українські народні думи та історичні пісні, що так само, поза сумнівом, не могли не залишити слід у душі обдарованого юнака.

С. Величко робить спробу за допомогою документів та інших матеріалів розібратися в тому, яку роль відіграв I. Виговський у житті України, вміщуючи портрет гетьмана в літопис. Портрет демонструє людину, впевнену в собі, досвідчену, шляхетського походження. 3 одного боку, він ілюструє вербальну характеристику, подану автором, з другого, - дає читачеві змогу сформувати власну оцінку щодо особистості гетьмана. І. Нечуй-Левицький співчуває людині з таким високим інтелектуальним потенціалом, яка, на жаль, не змогла його реалізувати на благо свого народу.

Іван Виговський, як й інші патріоти України, прагне втілити в життя ідеї Б. Хмельницького - відвернути Україну від темної Московщини, але вбачає вихід не в самостійності: „Визволимо Галичину і Волинь, зберемо весь наш український народ докупи, і пристанемо до хисткої Польщі і матимемо силу i снагу вдержати самостійність при слабкій Польщі"”2. Письменник засвідчує, що така ідея гетьмана була прогресивна, але не прийнятна для народу в той час.

Використання історичних джерел у творах Д. Мордовця мало, очевидно, орнаментальний характер, автор використовує їх не задля урізноманітнення композиції твору чи підсилення фабули, а скоріше демонструє власну обізнаність із джерелами чи то фольклорними, чи то історичними документами. Прототекстами його творів однаковою мірою стають народні думи та пісні, а також літопис Самовидця. Д. Мордовець написав серед інших історичні романи Дві долі, Палій (1902, обидва українською мовою), Цар і гетьман (1880), Великий розкол (1881), Сагайдачний (1882, всі - рос. мовою) та ін. Семен Палій дипломат, мудрий політик, талановитий військовий діяч, організатор козацької маси - таким був український полковник у реальному житті й таким постає він на сторінках твору Д. Мордовця. Письменник прагнув показати Палія не тільки в історії держави, але й зобразити живу людину з усіма іiї прагненнями та інтересами, недоліками та перевагами ${ }^{22}$. Повість Крымская неволя, написана на тему татарського полону напр. XVII ст.. Подаючи відомості з літопису Самовидця як історичний екскурс на початку повісті, автор визначає свою мету питанням: „Летописец говорит о церквах, иконах, крестах... А что было с людьми?!”23.

Історико-героїчна тема посідає важливе місце й у творчості Марка Вовчка. За кордоном Марко Вовчок написала кілька творів на історичні теми (Невільничка, Маруся, Кармелюк), розпочала повісті Сава Чалий і Гайдамаки, що лишилися незакінченими. Великий інтерес письменниці до історії України виник ще в немирівський період її життя й діяльності. Тоді і згодом вона читала історичні праці М. Бантиш-Каменського, М. Костомарова, М. Марковича, студіювала акти з історії України, цікавилась історичними піснями, легендами та переказами. Крім того, Марко Вовчок була близько знайома з П. Кулішем, який, вочевидь, ознайомив іiї з козацькими літописами.

Перу не дуже відомого в наш час письменника А. Кащенка належать історичні повісті та оповідання, що принесли йому найбільшу популярність: Над Кодацьким Порогом, Під Корсунем, У запалі боротьби, Славні побратими, Бориі за правду, На руїнах Січі, 3 Дніпра на Дунай, Зруйноване гніздо. Історич-

${ }^{21}$ I. Н Н ч у й - Ле в и ць к и й, Князь Сремія Вишневеиький; Гетьман Іван Виговський: історичні романи, Київ 1991, с. 332.

${ }_{22}$ Д. М орд о в ец ь, Сагайдачний: Повісті та роман, Львів 1989.

${ }^{23}$ Д. Мо рд о ве ц, Сагайдачный. Роман. Крымская неволя. Повесть, Київ 1987, с. 234. 
ний діапазон цих подій - 30-ті роки XVII ст. - кін. XVIII ст. Повість А. Кащенка Запорозька слава за художністю не належить до найкращих його творів, але вона цікава тим, що написана на матеріалі дослідження письменника про долю татарських бранців у Криму (трактат Бусурманська неволя в украӥнській народній поезії) та на літописній повісті Величка (у складі літопису) про страту Іваном Сірком тих визволених з татарської неволі бранців, які добровільно вирішили повернутися назад до Криму. Провідною ідеєю повісті, як і у творі Самійла Величка, є ідея вірності Батьківщині ${ }^{24}$.

Майже все своє життя А. Кащенко працював над книгою Оповідання про славне Військо Запорозьке низове. Це зразок його історичної публіцистики. Автор творив цю книжку паралельно з написанням повістей та оповідань. Деяка позірна безпристрасність і навіть протокольність окремих місць, така назагал невластива вдачі А. Кащенка, пояснюється, на наш погляд, його орієнтацією на певні літературні зразки — козацькі літописи, насамперед Самовидця та Величка ${ }^{25}$.

Отже, як видається, можливо визначити ще одну групу текстів, пов'язаних інтертекстуальними зв'язками з козацькими літописами - публіцистичні тексти. У наш час до козацьких літописів апелюють у друкованій пресі та онлайн. Напр., можемо прочитати статті з нагоди ювілею С. Величка: Літопис Самійла Величка надихнув Іллю Рєпіна на картину „, Запорожчуі пишуть листа турецькому султану” Людмили Кучеренко ${ }^{26}$ або_Про історію запорозького козацтвва ${ }^{27}$; Самійло Величко: літописещь козацької слави ${ }^{28}$ у Всеукраїнській незалежній суспільно-громадській газеті "Козацький край” та багато інших.

Такий значний корпус текстів, з яким козацькі літописи знаходяться в інтертекстуальній взаємодії в якості прототекстів, безперечно, можна розширити. Проте аналіз наведених прикладів дає підстави визначити основні типи інтертекстем, за допомогою яких ця взаємодія реалізується з різними групами текстів. Зазначене обумовлено особливостями дискурсивної приналежності. Так, 3 текстами науковими, історіографічними та публіцистичними інтертекстуальні зв'язки здійснюються через цитати, алюзії (номінативні), ремінісценції, репродукції (текстові). 3 текстами художнього дискурсу — через усі види інтертекстем, особливо цитати, алюзії, перекази, переклади, інтертекстеми як тропи та стилістичні фігури, інтермедіальні тропи та стилістичні фігури, запозичення прийому тощо.

Одним із прийомів трансформації в основі твору першоджерела $є$ його цитування із зазначенням джерела інформації: „этот рассказ киевлянина взят из „Летописи Самовидца” Изд. Ор. Левицкого” (с. 158-160) ${ }^{29}$. Прийом посилань „за свідченням літописців” виконує роль авторитетного джерела, однак важливим є не тільки конкретність походження наведених фактів, а ще й суголосність

${ }^{24}$ С. П і н ч у к, Слово про Адріана Кащченка, [в:] А. Кащенко, Оповідання про славне Військо Запорозьке Низове, Київ 1992, с. 4-8.

${ }_{25}$ Там само, с. 6-8.

${ }_{26}^{6}$ Л. Куче р е н ко, Літопис Самійла Величка надихнув Іллю Рєпіна на картину „, Запорожизі пишуть листа турецьькому султану”, [в:] „Вечірня Полтава”, № 42 (1077), [в:] Електронний pecypc: http://www.vechirka.pl.ua/articles/2013/2/13/25611480 (02.10.2013).

27 Про історію запорозького козацтвва, [в:] Електронний ресурс: http:/www.horting.org.ua/ node/1322 (12.06.2013).

${ }_{28}$ Самійло Величко: літописець козацької слави, [в:] Всеукраїнська незалежна суспільногромадська газета „Козацький край”, 10.02.2013, [в:] Електронний ресурс: http://cossackland.org.ua (01.07.2013).

${ }^{29}$ Д. Морд о в ец ь, Твори у 2 m., Київ 1958, т. 1, с. 235. 
3 думкою, яку висловлюють літописці. Моделюючи атмосферу історичної достовірності, автор твору дозволяє читачеві вийти за межі тексту твору, зануритись в епоху.

Вплив літописної традиції позначився й на сюжетно-композиційній структурі творів: детальний хронологічний звіт про події, що передували описуваним у творі. Крім того, в усіх аналізованих романах і повістях повторюються типові схеми ситуацій, схожість певних реакцій у подібних життєвих перипетіях; що дає можливість зробити висновок про визначальну роль літописів для пізнання письменниками історичного минулого у всіх його проявах громадського та світського, військового й родинного.

Отже, аналіз текстового матеріалу доводить, що, починаючи 3 др. пол. XIX ст., козацькі літописи привертають увагу науковців, письменників, журналістів і пересічних людей, які цікавляться історією України та українського козацтва й українською художньою літературою тощо. Тому інтертекстуальність дискурсу, в якому спостерігаються посилання на ці літописи, є розпізнаваною та актуальною.

Репрезентоване дослідження не вичерпує всього кола питань, пов'язаних із функціонуванням козацьких літописів як прототекстів. Недослідженими залишаються питання їхніх прокурсивних інтертекстуальних зв'язків із сучасними художніми творами. 